\title{
EVALUATION OF SOME FUNGI AND BACTERIA AS BIOLOGICAL AGENTS TO FUSARIUM WILT OF BANANA \\ Ziedan, E. H. ${ }^{1}$; Eman S. Farrag ${ }^{2}$ and Moataza M. Saad ${ }^{3}$ \\ 1- Plant Pathology Dept. National Res. Center, Cairo, Egypt. \\ 2- Agric. Botany Dept. Fac. of Agric. South Valley Univ. Quina, Egypt. \\ 3- Microbial chem. Dept. National Res. Center Cairo, Egypt.
}

\section{ABSTRACT}

Fusarium oxysporum Schlechtend: $\mathrm{Fr}$ f.sp . cubense (FOC) (E F. Smith). Snyder \& Hansen were the most causal organism causing wilt disease of banana plant at Beheira, Gharbea and Assuit Governorates, Egypt. Fusarium wilt disease of banana showed to be similar to those of other plants. Discoloration brown to dark of pseudostem and rhizomes was the most indicator of Fusarium wilt of banana plants.

In vitro four microbial isolates from the banana root and rhizosphere showed highly antagonistic activity to F.oxysporum f. sp. cubense. These isolates were identified as Bacillus subtilis (Ehrenberg) Cohn (No.1), Pseudomonas fluorescens Migula (No.3), Trichoderma harzainum Rifai (No.6) and Laetisaria arvalis Burds (4). Bacillus subtilis (Ehrenberg) Cohn (No.1); Pseudomonas fluorescens Migula (No.3) and T. harzianum isolates were the most antagonistic isolates inhibiting mycelial growth of $F$. oxysporum f.sp. cubense.These antagonistic strains were excreted antifungal lytic enzymes on liquid medium containing dead mycelium of $F$. oxysporum f. sp. cubense i.e. chitinase, $\beta 1-3, \beta 1-4$ glucanases and protease. Chitinase and protease enzymes were the most lytic produced by all antagonistic strains.while $\beta 1-3$ and $\beta 1-4$ glucanases were produced at a moderate rate.

Bacillus subtilis (Ehrenberg) Cohn (No.1) was the most antagonistic strain producing chitinase and protease followed by $L$. arvalis and $T$. harzianum. On the other hand, Bacillus subtilis and L. arvalis were the most antagonistic producing difusible and volatile antibiotics followed by $P$. fluorescens. while, $T$. harzianum was the least antagonistic phase of antibiotics. Pot trails conducted during a summer season, revealed that dipping banana roots transplanting root in the suspension of B.subtilis, P.fluorescens Migula, T.harzianum Rifai and Laetisaria arvalis Burds $3 \times 10^{8}$ (CFU/ ml ) for one and two hours or soil drench with 100 and $200 \mathrm{ml} /$ pot were effectively reduced wilt disease incidence of banana plants, respectively. Under field naturally infestation with F.oxysporum f.sp. cubense soil dranch of banana around rhizome region by suspension of B.subtilis, P.fluorescens Migula, T.harzianum Rifai, and fungicide (Topsin) reduced the wilt incidence than control . Soil drenched with $300 \mathrm{ml}$ of $B$. subtilis significantly reduced the wilt incidence by $50 \%$ compared with control. Whereas the $P$. fluorescens Migula failed to control Fusarium wilt. $B$ subtilis was the most promising biocontrol agent against wilt disease of banana.

Keywords: Banana, Fusarium oxysporum f.sp. cubense, biological control, Fusarium wilt .

\section{INTRODUCTION}

Banana ( Musa spp.) is one of the most important horticultural crops in tropical and subtropical countries. Banana disease (Fusarium wilt) is one of the most serious problems of banana plantation in the world. Fusarium wilt of banana caused by F.oxysporum f. sp. cubense ( FOC ) is considered to 
have originated in Southeast Asia probably in association with wild species or early land races (Jones, 1994 ). Chemical control of Fusarium wilt is economically impracticable and its efficient control has been based on the use of tolerant varieties of banana ( Stover and Simmonds, 1987 and Ploetz et al., 1990). The breeding programmes to obation the disease resistant plants is difficult in banana because the most of the widely cultivated varieties are triploids and have poor seed production ( Mastumoto et al., 1999 ). Currently, eight species of microorganisms are registered by the U.S.Environmental. Protection agencey of commerical use against soil borne plant pathogens in the Untited States. These include Trichoderma harzianum G-21, Gram negative bacteria(Pseudomonas fluorescens EG-1053) and Gram positive bacteria (Bacillus subtilis GB03, B. subtilis MBI 600 each of these microorganisms are intended to control damping- off diseases and improve stand establishment (Cook et.al., 1996). Biological control has been suggested an alternate method of controlling soil borne disease of banana by different methods(Sivamani \& Ganamanickam (1988), and Ziedan et.al.,2005) . Dipping banana sucters in the suspension of antagonistic isolates of $P$. fluorescens $\left(10^{6} \mathrm{CFU} / \mathrm{ml}\right)$ or T.viride $\left(10^{6} \mathrm{CFU} / \mathrm{ml}\right)$ along with application of $500 \mathrm{~g}$ wheat bran, were effectively reduced Fusarium wilt incidence and produced the highest yield (Raguchander et. al., 1997). Also , Narendrappa and Gowda , 1995 in USA found that soil application of banana with $P$. fluorescens strain Pf10 reduced the wilt incidence $50 \%$ compared with the control.

Thus the current studies were designed to evaluate banana antagonistic microorganisms to controlling Fusarium wilt under greenhouse and field conditions .

\section{MATERIALS AND METHODS}

\section{Isolation and identification of causal organisms}

Twenty samples of diseased banana roots and rhizomes were collected from Beheira, Gharbeia and Assiut Governorates. The diseased tissues were disinfected in $1 \%$ sodium hypochlorite solution for 2 min, rinsed in tap water three times and placed on sterilized tissue paper at room temperature until dry. The sterile tissues were then plated on potato dextrose agar ( PDA ), Czapek-s and peptone glucose agar media for 3-5 days at $25+2^{\circ} \mathrm{C}$. Fungal isolates were purified using hyphal tip and single spore culture techniques. Identification was carried inconsaltation with information from Gilman, (1957) ;Nelson et al.,(1983) and Barnett and Hunter (1998).

\section{Pathogenicity test}

Pathogenicity test was carried out in Plant Pathology Dept. ( NRC ), plastic pots $(30 \mathrm{~cm}$ - diameter ) containing clay sandy soil were infested with each fungal inoculum prepared by growing each fungal isolates in sterilized corn meal and sand medium ( $75 \mathrm{~g}$ corn meal grain $+25 \mathrm{~g}$ clean pur sand $+100 \mathrm{ml}$ water ) at $28 \AA \mathrm{C}$, for two weeks. Soil was infested with the rate of $10 \%(\mathrm{w} / \mathrm{w})$. Pots were watered every two days for a week before planting one plant of banana Cv. Williams was cultivated in each pot. Five pots were 
used for each isolate as replicates. Four months later, the percentage of wilt and disease severity were determined according to Woltz and Arthur, (1973), wheares:

$0=$ healthy plant, $1=$ yellowish $+1 / 3$ plant wilted, $2=2 / 3$ plant wilted, $3=$ whole plant wilted and $4=$ plant dead

\section{Host range of F.oxysporum}

Lupni ,cotton, watermelon , cowpea ,sesame,tomato , eggplant and pepper, were used for studying the host specific of F.oxysporum isolate revealed to be able to induce wilt disease of banana .

\section{Biological control studies \\ Isolation of rhizospheric microflora}

A number of bacterial and fungal were isolated from rhizospheric soil samples collected from banana growing areas of Beheira, and Gharbeia using the method adopted by (louw and Webley, 1959). Dilutions were made up to $1 \times 10^{-7}, 1 \times 10^{-4}$ for isolating bacteria and fungi respectively. Soil extract agar medium was used for bacterial isolation ( Skinner et al., 1952 ), peptone dextorse agar medium for fungal isolation (Martin , 1950 ) and one $\mathrm{ml}$ from the above dilutions was spreaded on the prepared media in a Petri-dish and four replicate were used. The bacterial and fungal were checked 2-5 days after incubation in dark at $28 \circ \mathrm{C}$.

Screening of antagonistic microorganisms to $F$. oxysporum f.sp cubense

The interaction between F.oxysporum f. sp. cubense and the rhizospheric microoganisms as well isolate of Laetisaraia arvalis which obtained during isolation traila of fungi associated banana infected plant by wilt disease were assaed in-vitro on (PDA ) according to (Ziedan ,1993). Inhibition or reduction in the linear growth of the pathogenic fungi were recorded 5 days after incubation at $27 \pm 2^{\circ} \mathrm{C}$ when mycelial growth covers the entire surface in control plates. The percentage of inhibition in mycelial growth of F.oxysporum f. sp. cubense was calculated using the formula as follows:

$$
I=(C-T / C) \times 100
$$

Whears: $I=$ Percentage of inhibition of F.oxysporum

$\mathrm{C}=$ linear growth of control (without antagonistic agent ) and $\mathrm{T}=$ linear growth of treatment.

\section{Identification of antagonistic microorganisms:}

Antagonistic bacterial isolates were identified according to morphological, physiological, and biochemical characters according to (Harrigan and McCane, 1976 and Sneath, 1986). Also, antagonistic fungal isolates were identified according to morphological characters (Gilman , 1957 and Barnett \& Hunter, 1998).

Antibiosis activity of antagonistic microorganisms toward $F$. oxysporum f.sp. cubense

Propagation of pathogenic fungi

The fungal isolate was grown in Erlenmeyer flasks $(250 \mathrm{ml})$ each containing $50 \mathrm{ml}$ of Czapek.s Dox broth medium supplemented with glucose 
as a sole source of carbon at a concentration of $1 \%(\mathrm{w} / \mathrm{v})$. Each flask was separately inoculated by one disk (4 $\mathrm{mm}$ - diameter) of a fungal growth and incubated shaken at $28 \pm 2{ }^{\circ} \mathrm{C}$ for 5 days, then the mycelium was then collected by filtration and dried to a constant weight.

\section{Production of difusible antibiotics}

Plates containing dextrose agar medium (PDA)were covered with a cellophane membrane, inoculated in the center with $100 \mu \mathrm{L}$ of antagonistic isolate suspention $\left(5 \times 10^{8} \mathrm{CFU} \mathrm{ml}-1\right)$. After incubation for $72 \mathrm{hrs}$ at $22^{\circ} \mathrm{C}$, the membrane with the grown isolate was involved and the plate inoculated in the middle with $10 \mathrm{~mm}$ mycelium disk of $F$. oxysporum f.sp. cubense. Plates were futher incubated at $22^{\circ} \mathrm{C}$ for $48 \mathrm{hrs}$ and the growth of the pathogen was measured.Control was run by sterile distilled water. Each experiment considering for each bacterial or fungal isolates. Treatments were run in triplicates and repeated at three times. Fungal growth of $F$. oxysporum f.sp cubense was determined of each antagonistic compare with in the control, according to (Press et al., 2001).

\section{Production of volatile antibiotics}

One hundred $\mu \mathrm{L}$ of antagonistic bacteria suspention $\left(5 \times 10^{8} \mathrm{CFU} \mathrm{ml} \mathrm{l}^{-1}\right)$ were placed at the center of one half Petri dish containing King's B medium. Disk $8 \mathrm{~mm}$ ( age 4 days) of pure culture $F$. oxysporum f.sp cubense was used for seeding placed at the center of another Petri dish containing PDA. Both half places were placed face to face perventing any physical contact between the pathogen and the antagonistic suspension and sealed to isolate the inside atmosphere and to prevent loss of volatiles formed. Plates were incubated at $22^{\circ} \mathrm{C}$ for $48 \mathrm{hrs}$ and the growth of the pathogen was measured in compared to the controls developed free antagonistic. Each experiment considering a single fungal or bacterial isolates were run in triplicate and repeated three times. Results are express as means of inhibition\% \pm S.D. of growth of $F$. oxysporum f.sp cubense according to (Press et al., 2001).

\section{Secretion of antifungal enzymes}

Trichoderma harzianum, Pseudomonas fluorescens, Bacillus subtilis and $L$. arvails were separately grown on a medium developed by Okon et al.(1973) which contained ( $\mathrm{g} / \mathrm{L}$ ): $\mathrm{MgSO}_{4} .7 \mathrm{H}_{2} \mathrm{O}, 0.2 ; \mathrm{K}_{2} \mathrm{HPO}_{4}, 0.9 ; \mathrm{KCl}$, $0.2 ; \mathrm{NH}_{4} \mathrm{NO}_{3}, 1.0 ; \mathrm{FeSO}_{4} .7 \mathrm{H}_{2} \mathrm{O}, 0.002 ; \mathrm{MnSO}_{4} . \mathrm{H}_{2} \mathrm{O}, 0.002$ and $\mathrm{ZnSO}_{4} .7 \mathrm{H}_{2} \mathrm{O}, 0.002$. This medium $(\mathrm{pH} 6.5)$ was supplemented with dead fungal mycelium (Fusarium oxysporum) as inducers for enzyme productions at a concentration of $1.0 \%$ and dispensed in Erlenmeyer flasks $(250 \mathrm{ml})$, each flask contained $50 \mathrm{ml}$ of medium. The flasks were autoclaved and inoculated with $1.0 \mathrm{ml}$ of precultured Trichoderma harzianum, Pseudomonas fluorescens, Bacillus subtilis and L. arvails The cultures were shaken incubated at $180 \mathrm{rpm}$. on a rotary shaker (New Brunswick Scientific Co.,USA) at $28 \pm 2^{\circ} \mathrm{C}$. Two flasks from each antagonistic isolate were analyzed daily for 5 days.

\section{Enzymes assay}

Chitinase activity was assayed following the release of $\mathrm{N}$ acetylglucosamine according to the method of Monreal and Reese (1969). One $\mathrm{ml}$ of $1 \%$ colloidal chitin in $0.1 \mathrm{M}$ citrate phosphate buffer $(\mathrm{pH} 6.5)$ was incubated with $1.0 \mathrm{ml}$ of culture filtrate at $37^{\circ} \mathrm{C}$ for $2 \mathrm{hrs}$. One unit of enzyme 
activity is defined as the amount of enzyme required to produce $0.5 \mu \mathrm{M} / \mathrm{ml}$ of $\mathrm{N}$ - acetylglucosamine per hour. Specific activity was expressed as units / $\mathrm{mg}$ protein.

$\beta$-1,4-glucanase activity was assayed following the release of free glucose from carboxy methyl cellulose ( CMC) as a substrate. The activity was defined and measured according to the method of Mandels et al. (1976). One unit of enzyme was defined as the amount of enzyme that releases1.0 $\mu \mathrm{M}$ of glucose / min. Glucose equivalents (reducing sugar) generated during assay were estimated by using 3,5 dinitrosalicylic acid (DNS) method (Miller, 1959), with glucose as standard.

$\beta-1,3$-glucanase activity was assayed by incubating $1 \mathrm{ml}$ of $0.5 \%(\mathrm{w} / \mathrm{v})$ laminarin in $0.1 \mathrm{M}$ sodium phosphate buffer, $(\mathrm{pH} 4.0)$ with $1 \mathrm{ml}$ of culture filtrate at $55^{\circ} \mathrm{C}$ for $5 \mathrm{~min}$. The reaction was stopped in an ice bath, $3 \mathrm{ml}$ of 3,5 dinitrosalicylic acid ( DNS ) reagent was then added and the mixture was heated in a boiling water- bath for $12 \mathrm{~min}$. As a control, $1 \mathrm{ml}$ laminarin solution was incubated and cooled, then $1 \mathrm{ml}$ of enzyme solution together with $3 \mathrm{ml}$ of DNS reagent were added to correct for the reducing sugars in the substrate and the enzyme solution. Reducing sugar equivalents were measured in both the original and the control solutions according to the method of Miller (1959), with glucose as standard.

For determination of protease activity, a reaction mixture containing $1.0 \mathrm{ml}$ of $1 \%$ soluble casein in $0.05 \mathrm{M}$-citrate phosphate buffer $(\mathrm{pH} 6.5)$ and $1.0 \mathrm{ml}$ of culture filtrate was used. The reaction mixture was incubated for $1 \mathrm{~h}$ at $37^{\circ} \mathrm{C}$ and was stopped by adding $10 \%$ trichloroacetic acid (TCA), kept for another $20 \mathrm{~min}$ at the same temperature and followed by centrifugation at $4000 \mathrm{rpm}$ for $20 \mathrm{~min}$. Samples of $75 \mu \mathrm{L}$ were removed and tyrosine was determined according to Lowry et al. (1951). One unit of the enzyme activity was defined as the amount of enzyme required for the formation of $1.0 \mu \mathrm{M}$. of the product / min of the reaction under the standard assay conditions.

\section{Biological control application \\ Pot experiment}

This experiment was carried out at National Research Center (NRC), Plant Pathology Dept in plastic pots ( $30 \mathrm{~cm}$-diameter) infested with $F$. oxysporium f.sp. cubense as mentioned before. Banana plant (Cv Williams) tissue culture transplants were used in this study. Pots were divided into two groups. First group banana transplants dipped roots for one and two hours

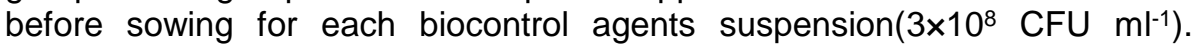
Second group, soil was drenched with 100 and $200 \mathrm{ml}$ of each agents suspension before sowing. One transplant was sown / pot. Four pots were used as replicates for each treatment and four plant were served as control according to Sivamani \&Ganamanickam,(1988) and Ziedan et. al.,(2005).

\section{Field application}

This experiment was carried out at Gharbeia Governorate. Infected banana plants (Cv. Williams )were used in this study. Soil around rhizomes drenched with different biological agents suspension (300 ml/plant). Each biocontrol agent $\left(3 \times 10^{8} \mathrm{CFU} / \mathrm{ml}\right)$ of B.subtilis, P.fluorescens, T.harzianum and $L$. arvails. Topsin $70 \%$ ( fungicide )was used by the rate $10 \mathrm{~g}$ suspended 
of $200 \mathrm{ml} /$ plates. Eight banana plant were used for each treatment and eight banana plants were served as a control.

\section{Prepartion of biocontrol agents inocula and inoculation method Fungal inocula}

Each isolate of Trichoderma harzianum and $L$. arvails were grown on PDA broth in Conical flask $250 \mathrm{ml}$ for 7 days at $27 \circ \mathrm{C} \pm 2 \stackrel{\circ}{\circ}$. Ten replicates were used for each isolate. Conidia spores and mycelial growth were harvested to obation fungal suspension $3 \times 10^{8} \mathrm{CFU} / \mathrm{ml}$, according to Ziedan et. al.,(2005).

\section{Bacterial inocula}

Each isolate of Bacillus subtilis and Pseudomonas fluorescens were individually grown on nutrient broth medium ( Beef $5 \mathrm{~g}$, peptone $3 \mathrm{~g}$ and distilled water $1000 \mathrm{ml}$ ) according to ATCC., $1984,100 \mathrm{ml}$ in sterilized medium for each conical flask $250 \mathrm{ml}$. Flasks were incubated at $30 \circ \mathrm{C}$ for $72 \mathrm{hrs}$. Cell suspension of each test bacterium were centrifuged at $400 \mathrm{~g} /$ min for 15 minutes and adjusted to $3 \times 10^{8} \mathrm{cell} / \mathrm{ml}$.

\section{Wilt disease assessments}

The precentage of banana wilted plants was determined, 3 months after sowing . Disease severity of shoot system was calculated as mentioned before. Also, disease severity of pseudostem basal and corms was determined according to percentage of discoloration area of cross section as follows:

$0=$ No discoloration

$1=25 \%$ discoloration

$2=50 \%$ discoloration

$3=75 \%$ discoloration

$4=100 \%$ discoloration

\section{Statistical analysis:}

The obtained data were statistically analyzed according to Snedecor and Cocharn (1980)

\section{RESULTS AND DISCUSSION}

\section{Survey of Fusarium wilt disease of banana plants}

The syndrome of Fusarium wilt of banana plants was commonly observed on the aerial plant parts showing yellowing, wilting, stunting and discoloration of pesudostem and rhizome of cross section at Gharbeia, Beheira and Assuit Governorates during 2002, 2003 and 2004.

\section{Symptomatology of banana wilt disease}

The expression of symptoms in wilt disease of banana caused by $F$. oxysporum sp. cubense showed in Fig.1 and Fig.2. The first visible sing of the disease, then tern to wilted followed by collapse of the petiole in the middle, the inner most leaves remain green and erect. Pseudostem is sometimes surrounded by a skirt of dead leaves in Fig (1). Longitudinal section of rhizomes showing discolouration brown to dark colour. Cross section of pseudostem is discoloration with purple colour Fig (1). These symptoms are considered the most diagnostic due to F.oxysporum f. sp. 
cubense (Stover and Simmonds, 1987, Jones, 1994, Ploetz et al., 1990 , Kung, 1995 and Moore et al., 1995). In this study disease severity of banana plants were grades in four group in Fig (2) as follows:

$\begin{array}{lll}0= & \text { healthy } ; & 1=\text { yellowish }+1 / 3 \text { plant leaves wilted } ; \\ 2= & 2 / 3 \text { plant leaves wilted } 3=\quad \text { whole leaves wilted } \\ 4= & \text { plant dead }\end{array}$

Fig (1) Fusarium wilt symptoms of banana plant (Cv. Williams)

A-External symptoms of banana leaves remain erect and yellowish

B-Internal symptoms of banana vascular discoloration in rhizome

C-Internal symptoms of banana discoloration of in pseudostem

$0=$ Healths, $1=25 \%$ discoloration, $2=50 \%$ discoloration, $3=100 \%$ discoloration

Isolation, identification and pathogenicity test of fungal isolates from banana

A number of fungal isolates from diseased banana with yellowing, wilting, stunting and discoloration of root system as shown in Figs 1 and 2 were prepared in pure culture. Isolates of F. oxysporum, Aspergillus niger and Macrophomina phaseolina from Beheira ,Gharbeia and Assuit were tested of banana (Cv. Williams one year - old).

Data in Table ( 1 ) show that $F$. oxysporum isolates from Beheria, Gharbeia and Assiut were the most and significantly pathogenic isolates induced wilt symptoms $66.5 \%, 33 \%$ and $66.5 \%$, respectivilly. Macrophomina phaseolina 
(Mauble)Ashby, isolated from Beheira induced root-rot syndrome (100\%) and disease severity (4.0). Laetisaria arvalis was used as biocontrol agent to in this study. Simillar results were obtained before by several investigators of banana wilt disease(Stover and Simmonds 1987; Ploetz et al., 1990; Mastumoto et al., 1999 and Jones, 1994 ; Conway et al.,2000\& Babba and Conway2003 ).

Fig(2) Disease severity of banana plant (Cv. Williams) infected by $F$. oxysporium f.sp. cubense

$0=$ healty plant

$2=2 / 3$ leaves wilted

\section{$1=1 / 3$ plant leaves wilted}

$3=$ whole leaves wilted

\section{Host range of $F$. oxysporum}

The studying of host range to the highly virulence $F$. oxysporum which able to induce wilt disease to banana plant and was failed to causing wilt symptoms, of the plants tested i.e. Tomato (Lycopersicon esculentum), Eggplant (Solanum nigrum), Sesame (Sesamum indicum L) Cv.Giza 32, Cotton (Gossypium spp.),Pepper (Capsium annum),Lupini (Lupinus terms) Cowpea (Vigno sineces Cv.) Black andWater melon (Cucurbita pepo $\mathrm{Cv}$.) Eskandarmnni. This result confirmed that the compelety identifiction of wilt causal of banana is formae specially F.oxysporum f. sp. cubense.

Table (1) Pathogenicity test of fungal isolates

\begin{tabular}{|l|l|c|c|c|}
\hline \multirow{2}{*}{ Location } & Fungal name & \multicolumn{3}{|c|}{ Wilt and root-rot of banana } \\
\cline { 3 - 5 } & & Infection \% & D. severity & Symptoms \\
\hline Beheira & Aspergillus niger & $00.0 \mathrm{~d}$ & $0.0 \mathrm{~b}$ & ----- \\
(Nobareia) & Aspergillus niger & $00.0 \mathrm{~d}$ & $0.0 \mathrm{~b}$ & ---- \\
& F. oxysporum & $66.5 \mathrm{~b}$ & $3.0 \mathrm{a}$ & wilt \\
& M. phaseolina & $100.0 \mathrm{a}$ & $4.0 \mathrm{a}$ & root-rot \\
\hline Gharbeia & Laetisaria arvalis & $00.0 \mathrm{~d}$ & $0.0 \mathrm{~b}$ & --- \\
& F.oxysporum & $33.0 \mathrm{c}$ & $2.0 \mathrm{a}$ & wilt \\
\hline Assiut & F. oxysporum & $66.5 \mathrm{~b}$ & $3.0 \mathrm{a}$ & wilt \\
\hline Check & Without & $00.0 \mathrm{~d}$ & $0.0 \mathrm{~b}$ & --- \\
\hline
\end{tabular}

Numbers within columns followed by the same letter are not significantly different at $\geq$ 0.05 . 
Fusarium wilts are caused by pathogenic Fusarium oxysporium. There are a high level of specificity between susceptible host plants and pathogenic $F$. oxysporium strains. This specificity is characterized by formae specials and races to which $F$. oxysporum belongs (Armstrong and Armstrong, 1981 )Biological control studies

\section{Screening antagonistic isolates}

Direct antagonism in dual culture between $F$. oxysporium and rhizospheric isolates was calculated in Table (2) show the isolated fungi and bacterial from banana rhizophere i.e bacterial isolates (B.subtilis and one isolate of $P$. fluorescens. Fungal isolates were including on $T$. harzianum and T. viride, 2 isolates of $A$. niger; one isolate of Pencillium sp. and one isolate of L. arvalis; T.harzianum, P. fluorescens. Bacillus subtilis ( No. 1) showed a highly antagonistic effect against F.oxysporum f.sp. cubense. A high reduction of pathogenic fungal growth by B.subtilis (No1), $P$. fluorescens , T. harzianum and L. arvalis .

Table(2) Antagonistic effect of banana rhizosphere microorganism to F.oxysporum f.sp. cubense.

\begin{tabular}{|l|c|c|}
\hline \multirow{2}{*}{ Microorganism } & \multicolumn{2}{|c|}{ F.oxysporum f.sp. cubense } \\
\cline { 2 - 3 } & R. Growth \% & Zone of inhibition (cm) \\
\hline Bacillus subtilis (1) & $72.00 \mathrm{a}$ & $3.1 \mathrm{a}$ \\
\hline Bacillus ssubtilis (2) & $00.00 \mathrm{~d}$ & $0.0 \mathrm{~d}$ \\
\hline P. fluorescens (3) & $27.00 \mathrm{c}$ & $3.0 \mathrm{a}$ \\
\hline L. arvalis (4) & $50.8 \mathrm{~b}$ & $2.0 \mathrm{~b}$ \\
\hline Penicillium sp. (5) & $66.7 \mathrm{a}$ & $0.0 \mathrm{~d}$ \\
\hline T.harzianum (6) & $72.2 \mathrm{a}$ & $2.5 \mathrm{~b}$ \\
\hline T. viride (7) & $50.0 \mathrm{~b}$ & $0.0 \mathrm{~d}$ \\
\hline Aspergillus niger (8) & $45.0 \mathrm{~b}$ & $0.9 \mathrm{c}$ \\
\hline Aspergillus niger (9) & $50.0 \mathrm{~b}$ & $1.0 \mathrm{c}$ \\
\hline
\end{tabular}

The fungal growth of the tested fungal was severly inhibited in the presence of B.subtilis (No1) followed by P. fluorescens. No physical contact was observed between any of the antagonistic isolates and F.oxysporum . Moreover, an inhibitory hallo was observed suggesting the presence of fungistic metabolites secreted by the isolates. It has been described that all isolates can secrete several antifungal metabolites such antibiotics or lytic enzymes (Brian and McGowan, 1945, Broadbent et. al., 1971,Dennis and Webster, 1971, Pérez et al., 2002 and Ziedan et. al.,(2005).

Difusible antibiotics and volatile antibiotics :

All antagonistic isolates gave inhibitory effect on the growth of F.oxysporum but Bacillus subtilis, L. arvalis and P. fluorescens showed the best inhibitory effect on the growth of F.oxysporum (Table 3). Such results are in line with those obtained by (Reddy and Rahe,1994), indicated that an antibiotic complex containing bacilysin and fengmycin (Fengycin) produced by Bacillus subtilis, Brian and McGowan, 1945 were described a highly fungistatic antibiotic, viridin produced by T.viride.Dennis and Webster (1971) showed that Trichoderma spp. produce antibiotics such as trichodermin by T.viride and T. polysporum and other peptide antibiotic by T. hamatum. 
Table (3) Effect of difsusible and volatile antibiotics secreted by antagonistic microorganisms on PDA at $22^{\circ} \mathrm{C}$ for $72 \mathrm{hrs}$

\begin{tabular}{|c|c|c|}
\hline \multirow[t]{2}{*}{ Isolates } & \multicolumn{2}{|c|}{ Inhibition of F.oxysporum \% } \\
\hline & difusible antibiotics & volatile antibiotics \\
\hline Bacillus subtilis & $33.94 a$ & $55.99 a$ \\
\hline P. fluorescens & $32.99 a$ & $54.97 a$ \\
\hline T.harzianum & $19.55 b$ & $21.22 b$ \\
\hline L. arvalis & $33.8 \mathrm{a}$ & $55.6 a$ \\
\hline
\end{tabular}

Secretion of antifungal enzymes by antagonistic isolates

Bacillus subtilis , $P$. fluorescens ,T.harzianum and $L$. arvalis.were selected after the observation of clear zones around the growing isolates on medium containing only dead mycelium of F.oxysporum mentioned in table (2) suggesting an lytic activity of these strains against F.oxysporum.

In order to determine the production of lytic enzymes , $1 \%$ of fungal mycelium were used as a sole carbon source in the medium inoculated with Bacillus subtilis , $P$. fluorescens T.harzianum and $L$. arvalis respectively . Percentages of lysis and lytic enzymes activities were determined. Data in Table (4) showed that Bacillus subtilis, $P$. fluorescens, T.harzianum and $L$. arvalis gave high chitinolytic activity $(50.2,43.5,40.6$ and 41.3 units/ ml respectively ) and protease( $61.3,22.8,56.4$ and 66.2 units / $\mathrm{ml}$ respectively) enzyme activities and completely lysed fungal mycelium after 72 hrs for Bacillus subtilis and $P$. fluorescens or $69 \mathrm{hrs}$ for T.harzianum and L. arvalis of incubation at $28 \pm 2^{\circ} \mathrm{C}$. On the other hand, $\beta 1,3$ and $\beta 1,4$ glucanase gave low enzyme activities It may be concluded that they use these two latter mechanisms of biocontrol as opposite to some fungal biocontrol microorganisms that also use fungal cell wall hydrolyzing enzymes within their biocontrol mechanisms (Dennis and Webster 1971,Pérez et al., 2002 and Ziedan et al., 2005).

Table(4) Lytic enzymes produced by antagonistic microorganisms grown on dead mycelium of F.oxysporum f.sp. cubense

\begin{tabular}{|l|c|c|c|c|c|c|}
\hline Organisms & $\begin{array}{c}\text { Residual dead } \\
\text { mycelium mg/50 } \\
\text { ml medium }\end{array}$ & Lysis & \% & & \multicolumn{4}{|c|}{ Lytic enzymes (units/ ml) } \\
\cline { 5 - 7 } & & chitinase & $\begin{array}{c}\boldsymbol{\beta}-\mathbf{1 , 3} \\
\text { glucanase }\end{array}$ & $\begin{array}{c}\boldsymbol{\beta} \mathbf{1 , 4} \\
\text { glucanase }\end{array}$ & protease \\
\hline Check & 1.0 & $0.0 \mathrm{a}$ & $0.0 \mathrm{a}$ & $0.0 \mathrm{a}$ & $0.0 \mathrm{a}$ & $0.0 \mathrm{a}$ \\
Bacillus subtilis & 0.0 & $100 \mathrm{~b}$ & $50.2 \mathrm{~b}$ & $10.4 \mathrm{~b}$ & $15.2 \mathrm{c}$ & $61.3 \mathrm{c}$ \\
P. fluorescens & 0.0 & $100 \mathrm{~b}$ & $43.5 \mathrm{~b}$ & $18.9 \mathrm{c}$ & $9.3 \mathrm{~b}$ & $22.8 \mathrm{~b}$ \\
T.harzianum & 0.0 & $100 \mathrm{~b}$ & $40.6 \mathrm{~b}$ & $12.1 \mathrm{~b}$ & $16.3 \mathrm{c}$ & $56.4 \mathrm{c}$ \\
L. arvalis & 0.0 & $100 \mathrm{~b}$ & $41.3 \mathrm{~b}$ & $11.3 \mathrm{~b}$ & $8.2 \mathrm{~b}$ & $66.2 \mathrm{c}$ \\
\hline
\end{tabular}

Numbers within columns followed by the same letter are not significantly different at $\geq$ 0.05 .

\section{Pot experiment}

Data in Table ( 5 ) indicate that all antagonistic microorganisms to causal wilt disease of banana which isolated from rhizosphere significatly reduced wilt disease incidence of banana plant with different inoculation techniques than the control (untreated plants), increasing inoculum rate or 
exposure period for each treatments increasing reduction of wilt disease percentage and disease severity .

Table (5) Effect of biological treatment on wilt disease of banana caused by F.oxysporum f.sp. cubense

\begin{tabular}{|l|c|c|c|c|c|c|c|c|}
\hline \multirow{3}{*}{ Treatment } & \multicolumn{4}{|c|}{ transplanting } & \multicolumn{3}{c|}{ Soil drench/pot } \\
\cline { 2 - 10 } & \multicolumn{2}{|c|}{ 1h } & \multicolumn{2}{c|}{ 2h } & \multicolumn{2}{c|}{$100 \mathbf{~ m l}$} & \multicolumn{2}{|c|}{ 200ml } \\
\cline { 2 - 9 } & Inf. \% & D.S & Inf\% & D.S & Inf\% & D.S & Inf\% & D.S \\
\hline B.subtilis & $00.0 \mathrm{a}$ & $0.0 \mathrm{a}$ & $0.0 \mathrm{a}$ & $0.0 \mathrm{a}$ & $50.0 \mathrm{~b}$ & $4.0 \mathrm{~b}$ & $0.0 \mathrm{a}$ & $0.0 \mathrm{a}$ \\
\hline P.fluorescens & $75.0 \mathrm{c}$ & $4.0 \mathrm{~b}$ & $25.0 \mathrm{~b}$ & $4.0 \mathrm{~b}$ & $25.0 \mathrm{a}$ & $4.0 \mathrm{~b}$ & $25.0 \mathrm{~b}$ & $4.0 \mathrm{~b}$ \\
\hline T.harzianum & $25.0 \mathrm{~b}$ & $4.0 \mathrm{~b}$ & $0.0 \mathrm{a}$ & $0.0 \mathrm{a}$ & $25.0 \mathrm{a}$ & $3.0 \mathrm{a}$ & $0.0 \mathrm{a}$ & $0.0 \mathrm{a}$ \\
\hline L. arvalis. & $25.0 \mathrm{~b}$ & $4.0 \mathrm{~b}$ & $0.0 \mathrm{a}$ & $0.0 \mathrm{a}$ & $25.0 \mathrm{a}$ & $4.0 \mathrm{~b}$ & $0.0 \mathrm{a}$ & $0.0 \mathrm{a}$ \\
\hline Chech & $100 \mathrm{~d}$ & $4.0 \mathrm{~b}$ & $100 \mathrm{c}$ & $4.0 \mathrm{~b}$ & $100 \mathrm{c}$ & $4.0 \mathrm{~b}$ & $100 \mathrm{c}$ & $4.0 \mathrm{~b}$ \\
\hline
\end{tabular}

Numbers within columns followed by the same letter are not significantly different at $\geq$ 0.05 .

Bacillus subtilis was the most antagonistic microbes significantly reduced wilt disease incidence of banana plant as root dipping and soil treatment with bacterial suspension followed by T.harzianum .

Meanwhile P.fluorescens was the least effective to suppress wilt disease of banana plants .

\section{Field appplication}

Data presented in Table (6) soil treatment around pseudostem with $300 \mathrm{ml}$ suspension $\left(3 \times 10^{8} / \mathrm{ml}\right)$, for each antagonstic microorganism i.e., B.subtilis and T.harzianum were the most effective for controlloing wilt disease of banana plant under natural infection than the P.fluorescens and in the untreated plant (control)

B.subtilis suppress external wilt syndrome of banana plant to $50 \%$ than $100 \%$ in case of control untreated plant and plant treatment with T.harzianum P.fluorescens and fungicide (Topsin). Also B.subtilis and T.harzianum were significally suppression internal wilt syndrome if corms and stem basal (discoloration percentage in cross section ) $50 \%$ than the control followed by P.fluorescens $30 \%$ and Topsin $12.5 \%$. Results are inagreement with those obtained by (Sivamani\& Gnanamanickam, 1988,Mardis and Poetz,1990, Narendrappa and Gowda, 1995, Raguchander et.al.,1997,Nasir et al., 1999). Bacillus species, as a group, offer several advantages over Fluorescent pseudomonas and other Gram-negative bacteria as seed inoculants for protection against root pathogens, including longer shelf, because of their ability to form endosporess and the broad- spectrum activity of their antibiotics. One of the best known examples is $B$. subtilis A13, isolated more than 25 years ago in Australia (Broadbent et al., 1971). Bacillus species as biocontrol agents can be enhanced using a protocol designed to isolate rootassociated, endospore- forming bacteria exclusively and then screening candidate strain against the species of the pathogens likely to cause root diseases on the same plants.

The use of biocontrol agent ( biological control) as a new approach in plant protection showed promising results in controlling certain plant disease to avoid environmental hazards have proven great efficacy in biocontrol of many plant diseases . 
Ziedan, E. H.et al.

Table (6) Effect of biological treatment on wilt disease of banana

\begin{tabular}{|l|c|c|c|c|}
\hline \multirow{2}{*}{ Treatment } & \multicolumn{4}{|c|}{ Wilt disease incidence } \\
\cline { 2 - 5 } & \multicolumn{2}{|c|}{ External } & \multicolumn{2}{c|}{ Internal } \\
\cline { 2 - 5 } & Inf \% & D. Severity & Inf \% & D. Severity \\
\hline Check & $100.0 \mathrm{~b}$ & $4.0 \mathrm{~b}$ & $100.0 \mathrm{c}$ & $3.3 \mathrm{~b}$ \\
P.fluorescens & $100.0 \mathrm{~b}$ & $4.0 \mathrm{~b}$ & $70.0 \mathrm{~b}$ & $3.2 \mathrm{~b}$ \\
T.harzianum & $100.0 \mathrm{~b}$ & $4.0 \mathrm{~b}$ & $50.0 \mathrm{a}$ & $4.0 \mathrm{~b}$ \\
B.subtilis & $50.0 \mathrm{a}$ & $2.0 \mathrm{a}$ & $50.0 \mathrm{a}$ & $2.5 \mathrm{a}$ \\
Topsin & $100.0 \mathrm{~b}$ & $3.9 \mathrm{~b}$ & $87.5 \mathrm{~b}$ & $3.3 \mathrm{~b}$ \\
\hline
\end{tabular}

Numbers within columns followed by the same letter are not significantly different at $\geq$ 0.05 .

\section{REFERENCES}

Armstrong, G. M. ,and Armstrong, J.K. (1981).Formae speciales and races of Fusarium oxysporium causing wilt diseases. In: Nelson, P.E.;T.A.T. Oussoun and R.J.Cook (eds) Fusarium: Diseases, Biology and Taxonomy, pp. 391-399. Pennsylvania State Univ. Press, Pennsylvania, U.S.A.

A.T.T.C.(1984). American Type culture Collection 13ed, Parklawn Drive Rochwill, Maryland, USA. Pp.433-477.

Babba,V. and Conway, K.E. (2003).Competitive saprophytic ability of Laetisaria arvalis compared with Sclerotium rolfsii,proc. okla. Acad.. Sci.,83:17-22.

Barnett, H. I ., and Hunter, B.H. ( 1998 ) . Illustarted Genera of Imperfect Fungi . Burgess Pub. Co . Minneopolis . Minnesota , $218 \mathrm{pp}$.

Brian, P.W., and McGowan,J.C.(1945). Viridin: Ahighly fungistatic substances produced by Trichoderma viride. Nature 156:144-145.

Broadbent, P.; Baker,K.F., and Waterworth, Y.(1971). Bacteria and actinomycetes antagonistic to fungal root pathogens in Australian soil. Aust. J.Biol.Sci.,24:925-944.

Conway,K.E.; Gerken D.A., and Sandbury M.A. (2000). Population dynamics of Laetisaria arvalis and Burkholderia cepacia, potential biocontrol agents in soil cres and thatch of creeping bentgrass (Agrostis palustris),proc.okla. Acad..Sci.,80:39-46.

Cook,R.H.,Brucart,W.L.,Coulson,J.R.,Goettel,M.S.,Humber,R.A., Lumsden,R.D.,Maddox,J.V.,McManus,M.L.,Moore,L.,Meyer,S.F.,Quim by,P.C.,Stack,J.P.andVaughn,J.L. (1996). Safty of microorganisms intended for pest and plant disease control:Framework for scientific evaluation.BiolControl 7: 333-351

Dennis, C., and Webster, J.(1971). Antagonistic properties of speciesgroups of Trichoderma. 1- Production of non -volatile antibiotics. Trans. Br.Mycol. Sco.52:25-39.

Gilman, C.J.(1957).Amannal of soil fungi(2nd Edn. lowa state colege Press USA.

Harrigan , W. F. and M.McCane ( 1976 ) . Laboratory Method , In Microbiology , Academic Press, New York, 361 pp . 
Jones, D.R , ( 1994 ). The characterization of isolates of Fusarium oxysporum f.sp cubense from Asia Infomusa 4 (2) :3-4

Kung, U.J.N. (1995) Fusarium wilt and other banana diseases in Kenya. Infomusa, 4(2): 14-16.

Louw, H. A , and D.W .Webley ( 1959 ). The bacteriology of root region of the oat plant grown under controlled pot culture condition. J Appl . Bacteriology .22:216-226

Lowry, O.; Rosebrough, N.; Farr, A. and Randall, R.(1951): Protein measurement with the Folin phenol reagent. J.Biol.Chem. 139: 265.

Mandels, M; Andreotti, R. and Roche, C.(1976). Measurement of saccharifying cellulose. In:Gaaden, E.L., Mandels, M., Reese, E.T.and Spano, L.A.eds. Enzymatic conversion of cellulosic materials:Technology and application. John Wiley and Sona. Inc. New York.pp21-33.

Mardis , J. and Poetz, R (1990) Biological control of diseases caused by Fusarium oxysporum. Fusarium wilt banana , 77:81.

Martin,S. J.P.(1950) .Use of acid, rose bengal and streptomycin in the plate method for estimating soil fungi .Soil Sci ., 64:215-223

Mastumoto, K; Souza, L.A.C and Barbosa ,M.(1999 ) In vitro selection of Fusarium wilt resistance in banana 1-co-cultivation technique to produce culture filtrate of race 1 Fusarium oxysporum f.sp. cubense .Fruits, 54 (2 ) 97-102.

Miller G.L.(1959). Use of dinitrosalicylic acid reagent for the determination of reducing sugars. Anal. Chem.31:426.

Monreal, J. and Reese, E.(1969).The Chitinase of Serratia marcescens. Can. J. Microbiol., 15:689.

Moore , N.Y. ; Bentley, S.; Pegg , K.G. and Jones , D.R (1995) Fusarium wilt of banana, Musa Dis. Fact-Sheet. (5) 499

Narendrappa , T. and Gowda , B.J. (1995) . Integrated management of Panama wilt cv. Nanjangud Rasabale . Current Research Univ. Agriculture Sciences Banagalore, 24(10):181-183.

Nasir, N; Pittaway , P.A.; Egg K.G. and Lisle, A.T (1999) A pilot study investigating the complexity of Fusarium spp. wilt of banana in West Sumatra, Indonesia . Aust . J. Agric Res., 50 (7) :1279-1283.

Nelson , P.E; Toussoum, T.A. and Marasas W.F.O (1983). Fusarium spp . An Illustrated Manual for Idenification. The Pennsylvania Univ, USA ,189 pp.

Okon,Y.; Chet, T.and Henis, Y.(1973). Effect of lactose , ethanol and cycloheximide on the translocation pattern of radioactive compound and on Sclerotium formation in Sclerotium rolfsii. J.Gen.Microbiol.,74:251.

Pérez, L.M..;Besoain,X.,Reyes,M.,Pardo,G. and Montealegre, J.(2002).The expression of extracellular fungal cell wall hydrolytic enzymes in different Trichoderma harzianum isolates correlate with their ability to control Pyrenochaeta lycopersici. Biological Research,35:401

Ploetz, R.C.; Herbert J.; Sebasigari K.; Hemandez J. H.; Pegg K.G.; Ventura J.A. and Mayato L.S. (1990) . Importance of Fusarium wilt in different 
banana growing regions In. R.C. Poltez (ED) Fusarium wilt of banana, PP. 9-26. Aps Press, Minnesota.

Press C.M.,Loper J.P. and KloepperJ.W.(2001) Role of iron in Rhizobacteriamediated induced systemic resistance of cucumber.Phytopathology 91: 593-598.

Raguchander ,T.;Jayashree, K. and Samiyappan , R.. (1997) Management of Fusarium wilt of banana using antagonistic microorganisms. J. Biological Control 11 (1-2) : 101-105.

Reddy, M.S. and Rahe,J.E.(1994). Bacillus subtilis B-2 and selected onion rhizobacteria in onion seedlings rhizosphere; effects on seedling growth and imdigenous rhizosphere microflora. Soil Biol.Biochem.21:379-383.

Sivamani,E.and Ganamanickam,S.S.(1988).Biological control of Fusarium oxysporium f.sp. cubence in banana by inoculum with Pseudomonas fluorescens.Plant and Soil,107: 133-137.

Skinner, F.A., P.G. Jones and J.E Molison ( 1952 ).A comparsion of direct and a plant counting technique for quantitative counts of soil microorganism. J. Gen Microbiol ., 6:261 -271

Sneath, P.H.A. ( 1986 ). Endospore forming gram positive rods and cocci. Pages 1104-1137.In : Bergy's Manual of Systemic Bacteriology vol. 2 Willams and Wilken, Baltimore, MD.

Snedecor , G.W. and Cochran, W.G. (1980). Statistical Methods $7^{\text {th }}$ ed. Lowa State Univ. Press, Ames.

Stover ,R. H. and Simmonds N.W (1987) Banana: 3 rd ed - (Tropical agriculture series ) Longman Scientific \& Technical, New York.

Woltz,S.S. and Arthur,W.E. (1973).Fusarium wilt of chrysanthemum:Effect of nitrogen source and time on disease development. Phytopathol.,63: 155-157.

Ziedan E.H.E (1993) Studies on Fusarium wilt disease of sesame( Sesamum indicum L.) in A.R.E. M.Sc Thesis, Faculty of Agric. , Ain Shams Univ., Egypt , 176 pp.

Ziedan, E.H.E.; Moataza, M. and Eman, S. (2005). Biological control of Grapevine root- rot by antagonistic microorganisms. The African Journal of Mycology and Biotechnology 13: 19.

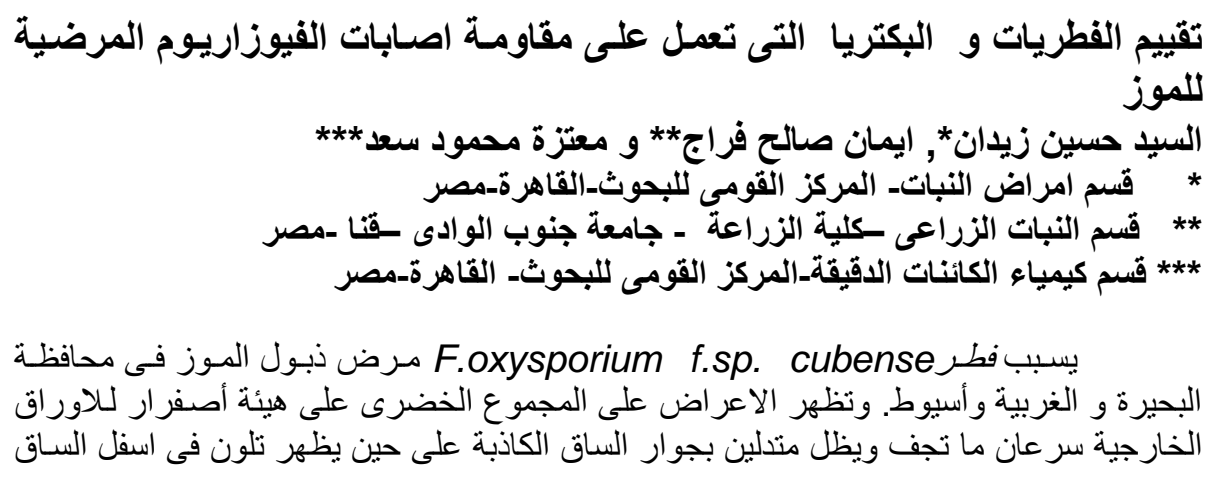


الكاذبة و الرايزوم ويمتاز ذلك الفطر أنـه متخصص لاصـابة نباتـات الموز دون غير هـا من النباتـات الاقتصادية الاخرى.

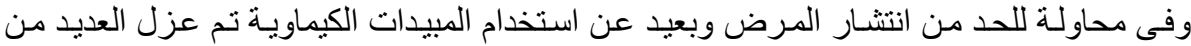

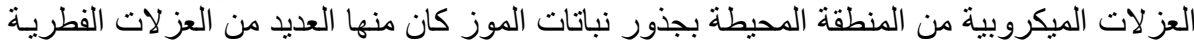

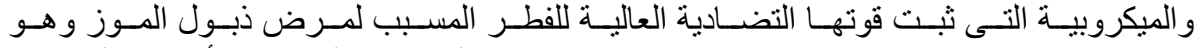
و.F.oxysporium fsp. cubense الفطر Trichoderma harzianum وعزلـة الفطر Laetisaria arvalis و وعز لنتين مسن البكتيريـ Bacillus subtilis و Pseudomonas fluorescences و وبعدل بعض وعزبن

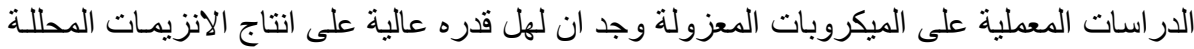

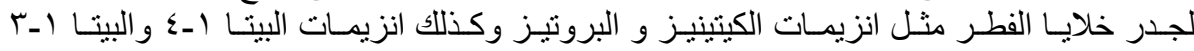

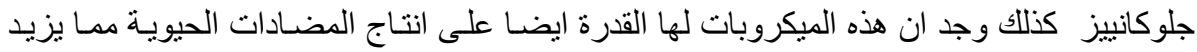

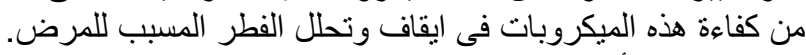

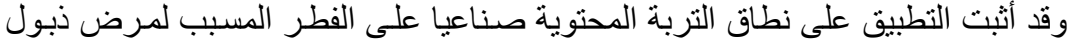

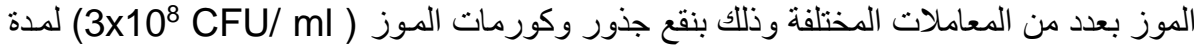

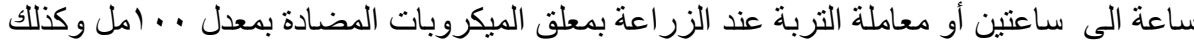

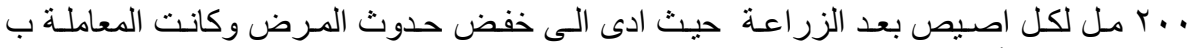

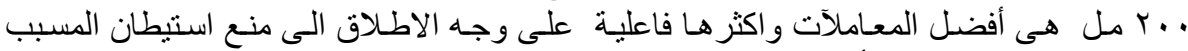

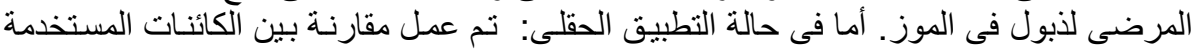

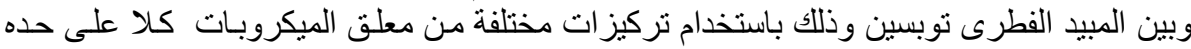

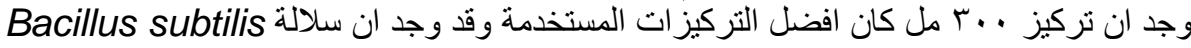

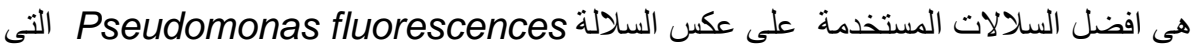

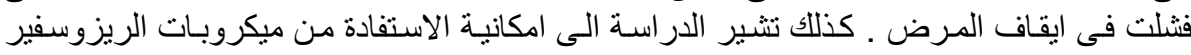

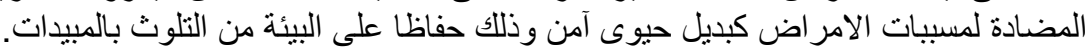

